\title{
KARAKTERISASI: LIMBAH CAIR INDUSTRI TAHU DENGAN KOAGULAN YANG BERBEDA (ASAM ASETAT DAN KALSIUM SULFAT)
}

\author{
Bara Yudhistira ${ }^{1)}$, Martina Andriani ${ }^{1)}$, Rohula Utami ${ }^{1)}$ \\ 1) Program studi Ilmu dan Teknologi Pangan, Fakultas Pertanian, Universitas Sebelas Maret \\ email: barayudhistira@yahoo.co.id
}

\begin{abstract}
Tofu liquid waste can be further processed to produce some useful product. That can be kept anaerobically to produce some organic acid. The purpose of this study to know the microbial growth behavior characteristic of liquid tofu waste which produce with different production process, such as specific growth rate $(\mu)$, doubling time (td), multiplication degree $(n)$, product yield, and efficiency of acetic acid production. This study is also aimed to identify the acid type which produce with different production tofu process. The liquid waste which used for this study is obtained from tofu producer which uses acetic acid and calcium sulfate to coagulate the tofu protein. Liquid tofu waste was incubated 24 hour, in ambient temperature $\left(30^{\circ} \mathrm{C}\right)$. analysis of total cell count, glucose concentration, acetic acid concentration, and $\mathrm{pH}$ value was evaluated in certain interval, such $0,2,4,68,10,12,14$ 16, 18, 20, 22, 24 hour. Acid type identification was evaluated in some phase during fermentation process. The observation result was plotted into a graphic which was shown the relationship of total cell count, with glucose concentration, acetic acid concentration, and also fermentation time. From the analysis of observation result, It can be concluded that, the specific growth rate of liquid tofu waste with acetic acid as protein coagulator is 0,3015/hour, while the specific growth rate of liquid tofu waste with calcium sulfate as protein coagulator is 0,2174/hour. The doubling time of liquid tofu waste with acetic acid as protein coagulator are 2,2991 hours, while the doubling time of liquid tofu waste with calcium sulfate as protein coagulator are 3,1877 hours. The multiplication degree of liquid tofu waste with acetic acid as protein coagulator are 2,605 times, while the multiplication degree of liquid tofu waste with calcium sulfate as protein coagulator are 1,880 times. The growth yield constant $(Y \mathrm{p} / \mathrm{s})$ of liquid tofu waste with acetic acid and calcium sulfate as protein coagulator respectively 8,1 $\times 10^{9} \mathrm{cfu} / \mathrm{mg}$ and $8,1 \times 10^{7} \mathrm{cfu} / \mathrm{mg}$. The product yield constant $(Y \mathrm{p} / \mathrm{s})$ of liquid tofu waste with acetic acid and calcium sulfate as protein coagulator respectively 1,7237 and 0,0306. The efficiency of acetic acid production during fermentation of liquid tofu waste with acetic acid and calcium sulfate as protein coagulator respectively $15,1376 \%$ and 2,5699\%. Acid type identification shows that acid which was contained in liquid tofu waste recognized as Acetic acid.
\end{abstract}

Keywords: biogas, tofu, waste,

\section{PENDAHULUAN}

Tahu merupakan salah satu jenis makanan yang sudah tidak asing lagi bagi masyarakat Indonesia. Umumnya tahu dikonsumsi sebagai lauk atau sebagai makanan ringan. Tahu merupakan makanan yang terdiri dari bahan dasar kacang kedelai yang telah dihancurkan dan proteinnya digumpalkan serta dibentuk menjadi bentuk seperti kotak pada umumnya.

Produksi tahu yang terdapat di Indonesia sebagian besar dilakukan oleh masyarakat yang termasuk golongan menengah ke bawah. Produksi tahu yang dilakukan masih secara tradisional, sehingga tidak adanya sistem yang mengatur pembuangan limbah hasil dari pembuatan tahu tersebut. Umumnya produsen tahu tidak mengolah limbah hasil pembuatan tahu dikarenakan biaya yang cukup mahal dan kurangnya pengetahuan dalam pengelolaan limbah.

Limbah tahu adalah bahan atau materi buangan yang timbul akibat kegiatan produksi tahu, yang sudah tidak dimanfaatkan lagi. Limbah yang dihasilkan berupa limbah padat dan cair. Limbah padat berupa ampas kedelai. Limbah cair berupa sisa air perendaman, sisa air tahu yang tidak menggumpal, serta limbah cair keruh berwarna kuning muda keabu-abuan yang apabila dibiarkan akan berubah menjadi hitam dan berbau busuk (Nurhasan dan Pramudyanto, 1991).

Pada umumnya limbah padat tahu dapat dimanfaatkan untuk makanan ternak. Sedangkan, limbah tahu yang berbentuk cair 
dibuang ke perairan sehingga mengakibatkan dampak buruk bagi kualitas air yaitu mengakibatkan bau busuk pada sungai atau tempat disekitar pembuangan limbah cair tahu tersebut. Keberadaan limbah cair dapat memberikan nilai negatif terhadap suatu kegiatan industri. Namun limbah cair tahu juga dapat memberikan nilai positif jika dapat memaksimalkan berbagai potensi yang ada pada limbah cair industri serta melakukan penanganan dengan teknologi yang tepat (Wijaya, 2008).

Pengelolaan limbah dalam industri pembuatan tahu merupakan salah satu dari contoh teknik pengelolaan limbah secara waste to product yaitu menggunakan kembali limbah industri tahu sebagai bahan baku produk baru yang memiliki nilai tambah. Upaya-upaya yang dapat dilakukan adalah pengolahan limbah cair tahu ini menjadi kecap tahu, pupuk cair, dan bahan bakar biogas serta dapat juga dilakukan untuk menghasilkan asam yang dapat digunakan kembali untuk proses penggumpalan susu tahu atau biasa disebut biang (Anonim ${ }^{\mathrm{a}}, 2010$ ).

Karakteristik limbah cair tahu dipengaruhi oleh metode atau cara pada proses pembuatan tahu. Proses pembuatan tahu dibedakan menjadi dua yaitu dengan penambahan $\mathrm{CH}_{3} \mathrm{COOH}$ (asam asetat) dan $\mathrm{CaSO}_{4}$ (kalsium sulfat) pada proses penggumpalan sari tahu (protein) menjadi tahu. Dengan adanya perbedaan bahan tambahan tersebut dimungkinkan menghasilkan limbah cair tahu yang berbeda pula. Limbah cair yang dihasilkan pada industri tahu ini akan mengalami proses yang dilakukan oleh mikrobia (secara spontan) selama pembuangan, hal ini terjadi dengan jalan menghidrolisis zat organik, seperti protein, karbohidrat, dan lemak yang masih terkandung dalam limbah cair tahu, tahap ini disebut dengan tahap hidrolisis. Tahapan selanjutnya yaitu tahap asidifikasi atau pengasaman yaitu proses pembentukan asamasam organik dari zat organik yang telah dihidrolisis pada tahap sebelumnya. Tahapan terakhir yaitu tahap pembentukan biogas hasil biokonversi dari asam organik yang dihasilkan. Sehingga diperlukan karakterisasi limbah cair tahu dengan perbedaan proses pembuatan tersebut. Salah satu karakterisasi yang dapat dilakukan diantaranya yaitu dengan kinetika pertumbuhan mikrobia pada limbah cair tahu untuk menghasilkan asam.
Sampai saat ini penelitian tentang limbah cair tahu lebih banyak ditujukan terhadap produktivitas dalam pembentukan produk yang dihasilkan (terutama produk yang mengalami fase asidifikasi atau fase pengasaman seperti proses pembentukan biogas), belum ada yang mempelajari tentang perilaku kinetika pertumbuhan mikrobia yang terjadi pada limbah cair tahu. Pada proses pembentukan biogas sendiri mengalami tahap asidifikasi yaitu tahap pembentukan asam yang selanjutnya akan dirubah menjadi biogas (gas metana). Dengan diketahuinya parameter kinetika pertumbuhan mikrobia yang memiliki produktivitas pembentukan asam yang tinggi maka dimungkinkan akan menghasilkan biogas yang tinggi pula. Hal ini melatarbelakangi perlu dilakukan penelitian mengenai pengaruh perbedaan proses pembuatan tahu sehingga dapat diketahui karakteristik dari masing-masing limbah cair tersebut, dengan diketahuinya parameterparameter kinetika pertumbuhan mikrobia dengan media limbah cair tahu meliputi kecepatan pertumbuhan spesifik, waktu penggandaan sel, derajat multipikasi, hasil pertumbuhan, efisiensi pembentukan asam serta jumlah asam yang diproduksi.

\section{METODE PENELITIAN}

Bahan utama yang digunakan penelitian ini adalah limbah cair yang berasal dari industri tahu yang menggunakan $\mathrm{CH}_{3} \mathrm{COOH}$ (asam asetat) dan $\mathrm{CaSO}_{4}$ (kalsium sulfat) dalam proses pembuatan tahu.

Bahan pembantu yang digunakan meliputi reagensia, indikator serta standar yang meliputi analisa kadar gula: larutan glukosa standar (10 mg glukosa anhidrat/ $100 \mathrm{ml}$ ), reagensia nelson $\mathrm{A}$ dan reagensia nelson $\mathrm{B}$ serta reagensia arsenomolibdat; analisa total asam: larutan $\mathrm{NaOH}$ dan indikator pp; analisa jumlah sel: media PCA, aquades; analisa jenis asam: standar asam asetat, asam butirat dan asam propionat (analisa GC).

Metode pelaksanaan penelitian ini yaitu sampel diambil dari industri tahu setelah proses produksi selesai dilakukan dengan menggunakan suatu wadah steril. Sampel yang telah diambil selanjutnya disaring dengan menggunakan kain saring untuk memisahkan padatan serta kotoran yang ada pada limbah cair tahu tersebut. Kemudian filtrat hasil saringan yang akan digunakan sebagai bahan 
untuk dilakukan penyimpanan (fermentasi) dan analisa.

Penyimpanan dilakukan pada suhu ruang selama 24 jam dalam kondisi anaerob. Analisa kadar gula, $\mathrm{pH}$, total asam, jumlah sel dan analisa jenis asam pada interval tertentu dilakukan analisa kadar gula, analisa $\mathrm{pH}$, analisa asam total, analisa jumlah sel dan analisa jenis asam. Pengamatan dilakukan pada jam ke: $0,2,4,6,8,10,12,14,16,18$, 20, 22, 24. Hasil pengamatan dibuat grafik yang menunjukan hubungan antara jumlah sel, kadar substrat (gula) serta kadar produk yang terbentuk (asam total) dengan waktu pengamatan. Masing-masing perlakuan dilakukan 2 kali ulangan sampel. Untuk analisa kualitatif dan kuantitatif asam yang dihasilkan diambil dari beberapa titik kinetika pertumbuhan mikrobia yang selanjutnya dilakukan dengan menggunakan kromatografi gas.

\section{HASIL DAN PEMBAHASAN}

\section{Pengaruh Perbedaan Penggumpal Tahu terhadap Jumlah Sel (cfu/ml), Kadar Glukosa (mg/ml), Kadar Asam Asetat (mg/ml), dan pH Limbah Cair Tahu}

Dalam penelitian ini dilakukan pengukuran perilaku kinetika pertumbuhan mikrobia pada limbah cair tahu yang menggunakan bahan penggumpal asam asetat $\left(\mathrm{CH}_{3} \mathrm{COOH}\right)$ dan kalsium sulfat $\left(\mathrm{CaSO}_{4}\right)$ serta sistem tertutup (batch process), karena tidak dilakukan lagi penambahan komponen substrat ke dalam sampel dan dilakukan penyimpanan selama 24 jam.

Perilaku kinetika pertumbuhan mikrobia pada masing-masing limbah cair tahu dengan perbedaan penggumpal (koagulan) dapat diketahui dengan melakukan pengamatan terhadap jumlah sel, kadar glukosa, dan kadar asam asetat. Selanjutnya hasil pengamatan aktivitas dari masing-masing limbah cair tahu yang berbeda disajikan dalam bentuk Grafik seperti pada gambar 1 dan gambar 2. Dari hasil pengamatan tersebut kemudian akan dibahas lebih lanjut tentang parameterparameter kinetika pertumbuhan mikrobia yang meliputi kecepatan pertumbuhan spesifik $(\mu)$, waktu penggandaan $(\mathrm{td})$, derajat multiplikasi/banyak penggandaan (n), hasil pertumbuhan (Growth Yield Constant) Y x/s , pembentukan produk (Produk Yield Constant) $\mathrm{Y}$ p/s dan efisiensi pembentukan asam asetat selama pengamatan. Dari kurva pertumbuhan dapat diketahui fase lag, fase log dan fase stasioner yang akan digunakan dalam penentuan atau perhitungan parameterparameter pertumbuhan mikroba.

Faktor lingkungan sangat berpengaruh pada pertumbuhan dan aktivitas antara lain:

1. Suhu

Dalam penelitian ini, selama pengamatan berlangsung suhu diatur pada suhu kamar $\left(30{ }^{0} \mathrm{C}\right)$. Bakteri dapat bekerja dengan baik pada suhu yang semakin tinggi sampai $40{ }^{\circ} \mathrm{C}$. Bakteri juga akan bekerja pada keadaan yang gelap dan tertutup (Sugiarto, 1987).

2. $\mathrm{pH}$

Pada penelitian ini $\mathrm{pH}$ awal limbah cair tahu dengan penggumpal asam asetat $\left(\mathrm{CH}_{3} \mathrm{COOH}\right)$ yaitu 3,91 dan $\mathrm{pH}$ akhir pengamatan 3,34 sedangkan untuk limbah cair tahu dengan penggumpal kalsium sulfat $\left(\mathrm{CaSO}_{4}\right) \mathrm{pH}$ awal yaitu 6,97 dan $\mathrm{pH}$ akhir pengamatan 5,12. Menurut Damanhuri, et al (1997), limbah cair tahu memiliki keasaman yang cukup rendah yakni 3-4.

3. Substrat

Bakteri pembentuk asam bertugas membentuk asam-asam organik seperti asam-asam butirat, propionat, laktat, asetat dan alkohol dari subtansi-subtansi polimer kompleks seperti protein, lemak dan karbohidrat. Proses ini memerlukan suasana yang anaerob. Tahap perombakan ini adalah tahap kedua dalam pembentukan biogas atau sering disebut tahap asidogenik (Macklin, 2009).

\section{Limbah Cair Tahu dengan Penggumpal asam asetat $(\mathrm{CH} 3 \mathrm{COOH})$}

Jumlah sel awal pada limbah cair tahu dengan penggumpal asam asetat $\left(\mathrm{CH}_{3} \mathrm{COOH}\right)$ adalah $4,1 \times 10^{7} \mathrm{cfu} / \mathrm{ml}$. Untuk fase lag berlangsung dari jam ke- 0 sampai jam ke-2, sedangkan untuk fase log dari jam ke-2 sampai dengan jam ke-8. Fase pertumbuhan maksimum dan stasioner berlangsung dari jam 10 sampai dengan jam ke-16. Fase kematian dari jam 18 sampai dengan selesainya pengamatan yaitu jam ke-24. Pada akhir fase log laju pertumbuhan mengalami perlambatan atau telah memasuki akhir fase logaritmik yang selanjutnya akan mencapai jumlah maksimal sel dan setelah itu akan mengalami fase stasioner dimana jumlah pertumbuhan sel 
seimbang dengan jumlah sel yang mati atau cenderung konstan. Jumlah sel pada jam ke-24 sebesar $1,7 \times 10^{8} \mathrm{cfu} / \mathrm{ml}$.

Kadar glukosa awal pada limbah cair tahu dengan penggumpal asam asetat $\left(\mathrm{CH}_{3} \mathrm{COOH}\right)$ $1,3263 \mathrm{mg} / \mathrm{ml}$ dan kadar glukosa setelah 24 jam sebesarr 0,2502 mg/ml. Kadar asam asetat awal menunjukkan $0,235 \mathrm{mg} / \mathrm{ml}$ dan mencapai kadar akhir sebesar $0,368 \mathrm{mg} / \mathrm{ml}$. Peningkatan kadar asam asetat yang dihasilkan beriringan dengan penurunan $\mathrm{pH}$. Tingkat keasaman atau pH awal menunjukkan 4,91 dan pH akhir 3,34.

Pada gambar 3 dapat dilihat bahwa selama 24 jam terjadi hubungan dimana kadar glukosa yang dalam hal ini sebagai substrat untuk pertumbuhan mikrobia akan terus mengalami penurunan dan kadar asam asetat sebagai produk hasil metabolisme (metabolit) akan mengalami kenaikan. Secara umum kadar glukosa terus mengalami penurunan karena dimanfaatkan oleh sel untuk tumbuh dan untuk membentuk produk berupa asam asetat. Semakin banyak kadar glukosa yang dimanfaatkan maka kadar asam asetat akan semakin meningkat. Menurut Wibowo (1990), bahwa komposisi kimia media cair mengalami perubahan karena nutrien akan dikonsumsi dan zat-zat metabolit akan diproduksi. Hal ini telah sesuai dengan teori dimana data hasil penelitian menunjukkan pola pertumbuhan sesuai dengan fase-fase pertumbuhan bakteri.

\section{Limbah Cair Tahu dengan Penggumpal Kalsium Sulfat $\left(\mathrm{CaSO}_{4}\right)$}

Pada limbah cair tahu dengan penggumpal kalsium sulfat $\left(\mathrm{CaSO}_{4}\right)$ akan dibahas hubungan antara parameter-parameter pertumbuhan mikrobia selama 24 jam. Hasil penelitian limbah cair tahu dengan penggumpal kalsium sulfat $\left(\mathrm{CaSO}_{4}\right)$ dapat diketahui hubungan antara jumlah sel, kadar glukosa, dan kadar asam asetat selama pengamatan dan digambarkan dalam bentuk grafik yang dapat dilihat pada gambar 2 .

Jumlah sel awal pada limbah cair tahu dengan penggumpal kalsium sulfat $\left(\mathrm{CaSO}_{4}\right)$ adalah $3,3 \times 10^{7} \mathrm{cfu} / \mathrm{ml}$. Untuk fase lag berlangsung dari jam ke-0 sampai jam ke-4, sedangkan untuk fase log dari jam ke-4 sampai dengan jam ke-10. Fase pertumbuhan maksimum dan stasioner berlangsung dari jam 12 sampai dengan jam ke-14. Fase kematian dari jam 16 sampai dengan selesainya pengamatan yaitu jam ke-24.
Jumlah sel awal pada limbah cair tahu dengan penggumpal kalsium sulfat $\left(\mathrm{CaSO}^{4}\right)$ adalah $3,3 \times 10^{7} \mathrm{cfu} / \mathrm{ml}$, Jumlah sel paling tinggi dicapai pada jam ke-12 dengan jumlah sel sebanyak $1,6 \times 10^{8} \mathrm{cfu} / \mathrm{ml}$ (Tabel 4), setelah jam ke-12 mencapai jumlah sel maksimum sehingga jumlah selnya akan mengalami penurunan. Jumlah sel pada jam ke- 24 sebanyak $9,0 \times 10^{7} \mathrm{cfu} / \mathrm{ml}$.

Pada gambar 2 dapat dilihat bahwa selama pengamatan terdapat hubungan dimana kadar glukosa dan $\mathrm{pH}$ akan terus mengalami penurunan dan kadar asam asetat akan mengalami kenaikan. Kadar glukosa awal $5,3038 \mathrm{mg} / \mathrm{ml}$ dan kadar akhir 3,3194 mg/ml. Kadar asam asetat pada awal pengamatan $0,030 \mathrm{mg} / \mathrm{ml}$ dan pada akhir pengamatan 0,120 $\mathrm{mg} / \mathrm{ml}$. Pada awal pengamatan $\mathrm{pH}$ limbah cair tahu dengan penggumpal kalsium sulfat $\left(\mathrm{CaSO}_{4}\right)$ menunjukkan pH 6,97 dan pada akhir pengamatan mencapai $\mathrm{pH} 5,12$. Pemberian zat penggumpal berupa $\mathrm{CaSO}_{4}$ juga akan memberikan pengaruh pada keasaman limbah cair yang dihasilkan. Limbah yang dihasilkan memiliki $\mathrm{pH}$ yang mendekati netral (Santoso, 1993).

Berdasarkan gambar 1 dan gambar 2, dapat diketahui bahwa selama pengamatan berlangsung (24 jam) terjadi peningkatan jumlah sel pada kedua sampel limbah cair tahu yang diuji. Untuk jumlah sel awal terjadi perbedaan jumlah sel pada sampel limbah cair tahu dengan penggumpal asam asetat $\left(\mathrm{CH}_{3} \mathrm{COOH}\right)$ berbeda dengan limbah cair tahu dengan penggumpal kalsium sulfat $\left(\mathrm{CaSO}_{4}\right)$ masing-masing sebesar $4,1 \times 10^{7} \mathrm{cfu} / \mathrm{ml}$ dan $3,3 \times 10^{7} \mathrm{cfu} / \mathrm{ml}$. Polprasert (1989) dalam Uniek (1999), melaporkan jumlah bakteri dalam limbah cair tahu berkisar $10^{5}$ sampai dengan $10^{8} \mathrm{cfu} / \mathrm{ml}$. Jumlah sel maksimum untuk kedua sampel limbah cair tahu pada jam yang berbeda yaitu untuk limbah cair tahu dengan penggumpal asam asetat $\left(\mathrm{CH}_{3} \mathrm{COOH}\right)$ terjadi pada jam ke 10 sedangkan untuk limbah cair tahu dengan penggumpal kalsium sulfat $\left(\mathrm{CaSO}_{4}\right)$ jumlah sel maksimum dicapai pada jam ke 12. Secara umum $\mathrm{pH}$ optimum bakteri sekitar $\mathrm{pH}$ 7, sedangkan untuk bakteri asidofilik obligat (Thiobacillus, Sulfolobus) tumbuh pesat pada $\mathrm{pH}$ 2. Pada umumnya bakteri tumbuh seiring dengan turunnya $\mathrm{pH}$ atau suasana medium menjadi asam yang disebabkan terbentuknya produk (asam) dari kegiatan metabolisme. Tingkat keasaman $(\mathrm{pH})$ akan mempengaruhi aktivitas enzimatis 
mikrobia yaitu ionisasi kimiawi dan transportasi nutrisi dan zat racun ke dalam sel

(Bitton, 2005).

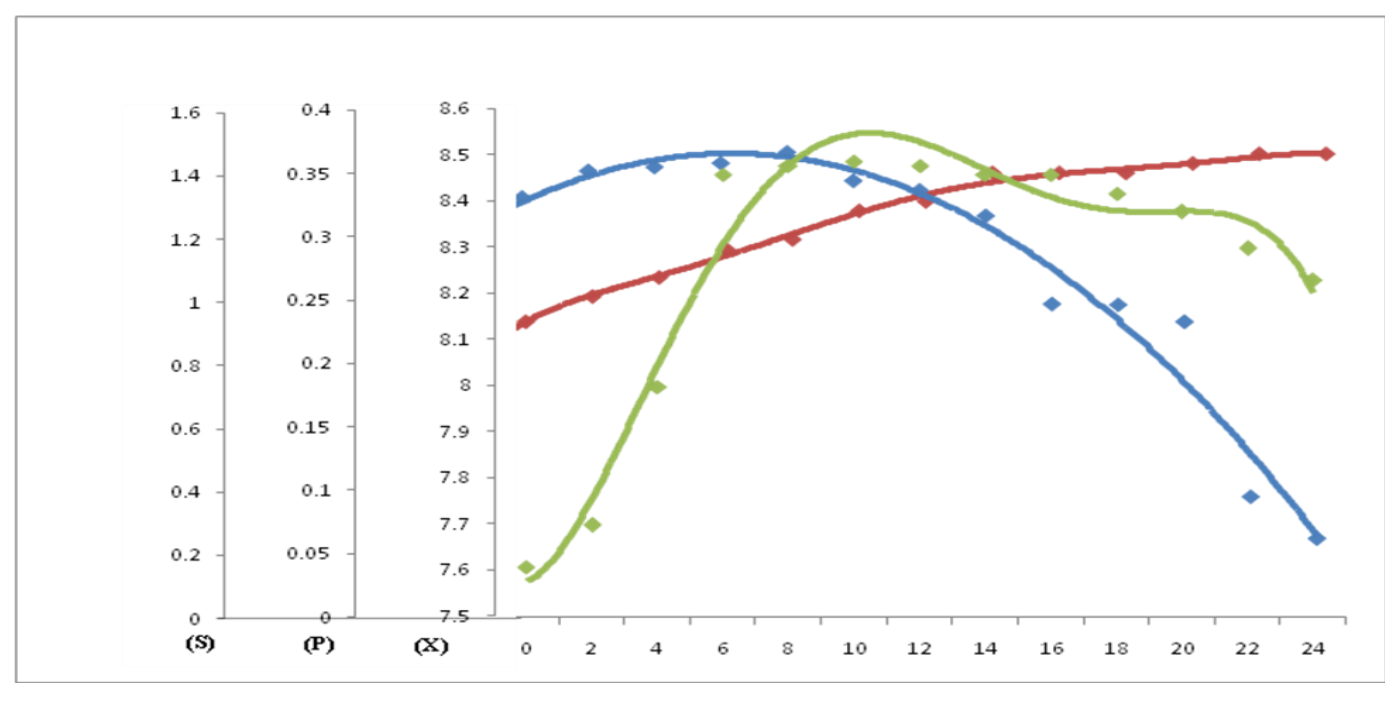

Keterangan gambar :

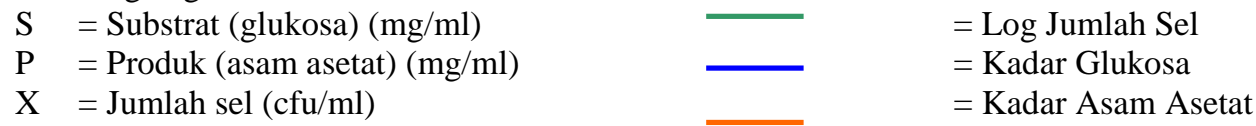

Gambar 1. Hubungan antara log jumlah sel, kadar glukosa, kadar asam asetat selama 24 jam pada limbah cair tahu dengan penggumpal asam asetat $\left(\mathrm{CH}_{3} \mathrm{COOH}\right)$.

Jumlah glukosa awal limbah cair tahu dengan penggumpal asam asetat $\left(\mathrm{CH}_{3} \mathrm{COOH}\right)$ $1,3263 \mathrm{mg} / \mathrm{ml}$ lebih sedikit daripada jumlah glukosa awal pada limbah cair tahu dengan penggumpal kalsium sulfat $\left(\mathrm{CaSO}_{4}\right)$ sebesar $5,3038 \mathrm{mg} / \mathrm{ml}$. Sesuai penelitian Kuswardhani (1985), kandungan glukosa pada limbah cair tahu yang digumpalkan dengan kalsium sulfat $\left(\mathrm{CaSO}_{4}\right)$ lebih tinggi dibandingkan penggumpal dengan asam asetat $\left(\mathrm{CH}_{3} \mathrm{COOH}\right)$.

Pada kedua jenis limbah baik limbah cair tahu yang digumpalkan dengan asam asetat $\left(\mathrm{CH}_{3} \mathrm{COOH}\right)$ dan limbah cair tahu yang digumpalkan dengan kalsium sulfat $\left(\mathrm{CaSO}_{4}\right)$ mengalami peningkatan jumlah substrat (glukosa) selama pengamatan 24 jam dapat dilihat pada gambar 1 dan gamabr 2. Untuk limbah cair tahu yang digumpalkan dengan asam asetat $\left(\mathrm{CH}_{3} \mathrm{COOH}\right)$ peningkatan kadar glukosa terjadi pada jam ke-0 sampai dengan jam ke-8, sedangkan limbah cair tahu yang digumpalkan dengan kalsium sulfat $\left(\mathrm{CaSO}_{4}\right)$ peningkatan kadar glukosa berlangsung dari jam ke-0 sampai dengan jam ke-12. Peningkatan kadar glukosa disebabkan karena adanya proses hidrolisis secara eksternal oleh enzim ekstraseluler mikroorganisme dari polisakarida menjadi monosakarida (glukosa) (Amaru, 2004). 


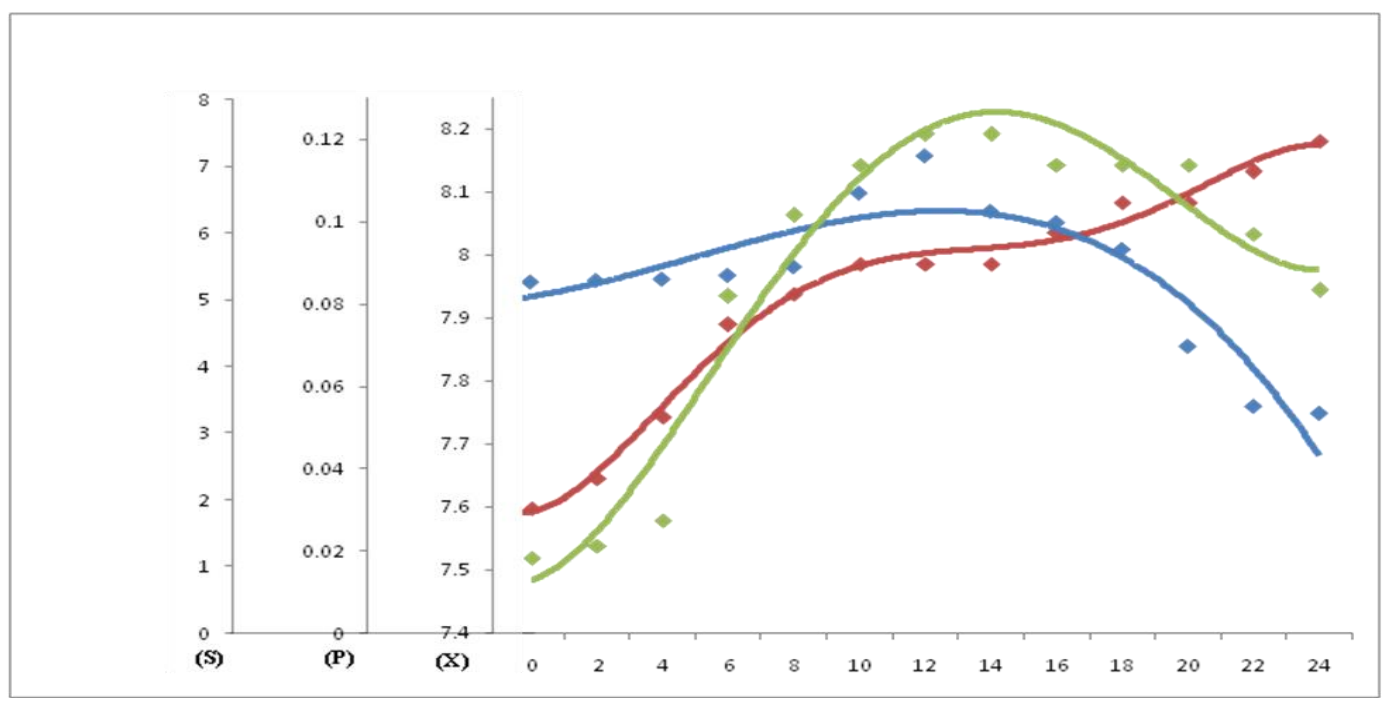

Keterangan gambar :

$\mathrm{S} \quad=$ Substrat (glukosa) $(\mathrm{mg} / \mathrm{ml})$

$\mathrm{P} \quad=$ Produk (asam asetat) $(\mathrm{mg} / \mathrm{ml})$

$\mathrm{X} \quad=$ Jumlah sel $(\mathrm{cfu} / \mathrm{ml})$

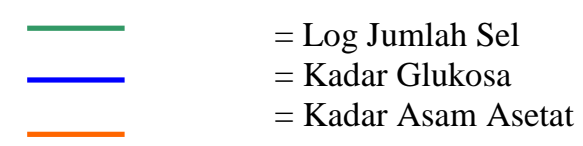

Gambar 2. Hubungan antara log jumlah sel, kadar glukosa, kadar asam asetat selama 24 jam pada limbah cair tahu dengan penggumpal kalsium sulfat (CaSO4).

Proses yang terjadi pada limbah cair tahu ini adalah fermentasi spontan secara anaerob. Terdapat beberapa jenis mikroorganisme yang terdapat pada sistem ini, yaitu bakteri hidrolitik, bakteri asedogenik, serta bakteri asetogenik. Bakteri hidrolitik memecah molekul organik komplek (protein, selulosa, lignin, lemak) menjadi molekul monomer yang terlarut seperti asam amino, glukosa, asam lemak, dan gliserol. Molekul monomer ini dapat langsung dimanfaatkan oleh kelompok bakteri berikutnya. Bakteri asidogenik (pembentuk asam) seperti Clostridium merubah gula, asam amino, dan asam lemak menjadi asam organik (seperti asam asetat, propionat, formiat, laktat, butirat, atau suksinat), alkohol dan keton (seperti etanil, metanol, gliserol, aseton), asetat, $\mathrm{CO}_{2}$ dan $\mathrm{H}_{2}$. Sedangkan Bakteri asetogenik (bakteri yang memproduksi asetat dan $\mathrm{H}_{2}$ ) seperti Syntrobacter wolinii dan Syntrophomonas wolfei merubah asam lemak (seperti asam propionat, asam butirat) dan alkohol menjadi asetat, hidrogen, dan karbon dioksida, yang digunakan oleh bakteri pembentuk metana (metanogen). Komponen - komponen makromolekul akan dihidrolisis oleh ketiga jenis bakteri tersebut dan hasil akhirnya berupa asam asetat (polisakarida menjadi sakarida) (Bitton, 2005).

Berdasarkan pembahasan diatas dapat diketahui kesimpulan pengaruh jenis limbah cair tahu terhadap kinetika pertumbuhan mikrobia ke dalam suatu bentuk tabel 1 .

Tabel 1. Pengaruh jenis limbah cair terhadap parameter pertumbuhan mikrobia

\begin{tabular}{ccccccc}
\hline Jenis limbah & $(\mu)$ & $\mathrm{td}$ & $\mathrm{n}$ & $\mathrm{Y} \times / \mathrm{s}$ & $\mathrm{Y} \mathrm{p} / \mathrm{s}$ & Efisiensi \\
\hline $\begin{array}{c}\text { Penggumpal asam asetat } \\
\text { Penggumpal kalsium } \\
\text { sulfat }\end{array}$ & 0,3015 & 2,2991 & 2,605 & $8,1 \times 109$ & 1,7237 & 15,1376 \\
& 0,2174 & \multirow{2}{*}{3,1877} & \multirow{2}{*}{1,880} & $8,1 \times 107$ & 0,0306 & 2,5699 \\
\hline
\end{tabular}


Karakterisasi: Limbah Cair Industri Tahu ... Yudhistira et al.

Tabel 2. Pengaruh jenis limbah cair tahu terhadap jenis asam yang dihasilkan

\begin{tabular}{ccccc}
\hline \hline Jenis limbah & $\begin{array}{c}\text { Jam } \\
\text { pengamatan }\end{array}$ & $\begin{array}{c}\text { Asam asetat } \\
(\mathrm{mg} / \mathrm{ml})\end{array}$ & $\begin{array}{c}\text { Asam propionat } \\
(\mathrm{mg} / \mathrm{ml})\end{array}$ & $\begin{array}{c}\text { Asam butirat } \\
(\mathrm{mg} / \mathrm{ml})\end{array}$ \\
\hline \multirow{3}{*}{ Penggumpal asam asetat } & 0 & 0,93522 & - & - \\
& 2 & 1,13736 & - & - \\
& 8 & 1,89066 & - & - \\
Penggumpal kalsium sulfat & 24 & 1,90482 & - & - \\
& 0 & 0,33642 & - & - \\
\hline \hline
\end{tabular}

\section{Analisis Jenis Asam Selama Pengamatan 24 Jam}

Dari tabel 2, dapat diketahui secara kuantitatif asam yang dihasilkan dari limbah cair tahu dengan penggumpal asam asetat $\left(\mathrm{CH}_{3} \mathrm{COOH}\right)$ dan limbah cair tahu yang digumpalkan dengan kalsium sulfat $\left(\mathrm{CaSO}_{4}\right)$ dengan menggunakan kromatografi gas (GC). Analisa dilakukan pada jam tertentu selama pengamatan, yaitu pada awal pengamatan, awal fase $\log$, akhir fase $\log$ dan pada akhir pengamatan untuk masing-masing sampel. Pada awal pengamatan untuk masing-masing sampel yaitu pada jam ke-0, selanjutnya untuk awal fase log pada sampel limbah cair tahu dengan penggumpal asam asetat $\left(\mathrm{CH}_{3} \mathrm{COOH}\right)$ dimulai pada jam ke-2 dan berakhir pada jam ke-8. Sedangkan pada limbah cair tahu yang digumpalkan dengan kalsium sulfat $\left(\mathrm{CaSO}_{4}\right)$ fase $\log$ diawali pada jam ke-4 dan berakhir pada jam ke-10. Akhir pengamatan selesai pada jam ke-24 untuk kedua sampel.

Hasil analisa jenis asam pada sampel limbah cair tahu dengan penggumpal asam asetat $\left(\mathrm{CH}_{3} \mathrm{COOH}\right)$ menunjukan hanya terdeteksi jenis asam asetat, sedangkan untuk asam propionat dan asam butirat tidak terdeteksi pada semua waktu pengamatan yang sampelnya dianalisa. Adapun jumlah asam asetat sampel limbah cair tahu dengan penggumpal asam asetat $\left(\mathrm{CH}_{3} \mathrm{COOH}\right)$ pada jam ke-0, jam ke-2, jam ke-8 dan jam ke-24 adalah berturut-turut yaitu $0,93522 \mathrm{mg} / \mathrm{ml}$; $1,13736 \mathrm{mg} / \mathrm{ml} ; 1,89066 \mathrm{mg} / \mathrm{ml}$ dan 1,90482 $\mathrm{mg} / \mathrm{ml}$.

Pada sampel limbah cair tahu yang digumpalkan dengan kalsium sulfat $\left(\mathrm{CaSO}_{4}\right)$ menunjukan hasil yang sama dengan limbah cair tahu dengan penggumpal asam asetat $\left(\mathrm{CH}_{3} \mathrm{COOH}\right)$ yaitu hanya terdeteksi jenis asam asetat. Sedangkan untuk jumlah asam asetat pada jam ke- 0 , jam ke-4, jam ke-10 dan jam ke-24 yaitu masing-masing $0,33642 \mathrm{mg} / \mathrm{ml}$;
$0,63942 \mathrm{mg} / \mathrm{ml} ; 0,87324 \mathrm{mg} / \mathrm{ml}$ dan 0,99552 $\mathrm{mg} / \mathrm{ml}$.

Dari kedua sampel limbah cair tahu baik limbah cair tahu dengan penggumpal asam asetat $\left(\mathrm{CH}_{3} \mathrm{COOH}\right)$ maupun limbah cair tahu yang digumpalkan dengan kalsium sulfat $\left(\mathrm{CaSO}_{4}\right)$ mengalami peningkatan jumlah asam asetat pada jam yang dianalisa. Pada limbah cair tahu dengan penggumpal asam asetat $\left(\mathrm{CH}_{3} \mathrm{COOH}\right)$ pada awal pengamatan jumlah asam asetat $0,93522 \mathrm{mg} / \mathrm{ml}$ meningkat menjadi $1,90482 \mathrm{mg} / \mathrm{ml}$ pada akhir pengamatan. Dari Tabel 13, dapat dilihat pada sampel limbah cair tahu dengan penggumpal asam asetat $\left(\mathrm{CH}_{3} \mathrm{COOH}\right)$ selama fase log (jam ke-2 sampai jam ke-8) mengalami peningkatan jumlah produksi asam asetat dari $1,13736 \mathrm{mg} / \mathrm{ml}$ sampai dengan $1,89066 \mathrm{mg} / \mathrm{ml}$, peningkatan ini sebesar $66,23 \%$. Pembentukan asam asetat termasuk kedalam metabolit primer yang diproduksi selama fase pertumbuhan eksponensial (fase log), disebut juga sebagai trophophase (Sardjono, 1999). Begitu juga untuk limbah cair tahu yang digumpalkan dengan kalsium sulfat $\left(\mathrm{CaSO}_{4}\right)$ mengalami peningkatan jumlah asam asetat sebesar $36,57 \%$ selama fase log (jam ke-4 sampai jam ke-10) yaitu asam asetat yang dihasilkan dari $0,63942 \mathrm{mg} / \mathrm{ml}$ menjadi $0,87324 \mathrm{mg} / \mathrm{ml}$.

Secara umum jumlah asam asetat yang dihasilkan pada sampel limbah cair tahu dengan penggumpal asam asetat $\left(\mathrm{CH}_{3} \mathrm{COOH}\right)$ lebih tinggi daripada limbah cair tahu yang digumpalkan dengan kalsium sulfat (CaSO4). Hal ini terjadi akibat pada limbah cair tahu dengan penggumpal asam asetat $\left(\mathrm{CH}_{3} \mathrm{COOH}\right)$ bakteri asetogenik bekerja lebih optimum dibandingkan pada limbah cair tahu yang digumpalkan dengan kalsium sulfat $\left(\mathrm{CaSO}_{4}\right)$. Pada umunya keadaan lingkungan sangat berpengaruh pada pertumbuhan dan aktivitas mikrobia. Faktor yang pertama yaitu suhu, untuk suhu pada kedua sampel baik limbah 
cair tahu dengan penggumpal asam asetat $\left(\mathrm{CH}_{3} \mathrm{COOH}\right)$ maupun limbah cair tahu yang digumpalkan dengan kalsium sulfat $\left(\mathrm{CaSO}_{4}\right)$ dilakukan penyimpanan pada suhu yang sama yaitu pada suhu $\pm 30{ }^{\circ} \mathrm{C}$ (suhu kamar). Jadi untuk faktor suhu tidak terkait pada perbedaan aktivitas (produksi metabolit/asam asetat) pada kedua sampel. Selanjutnya faktor yang kedua yaitu $\mathrm{pH}$, seperti disampaikan Bitton (2005) bahwa secara umum $\mathrm{pH}$ optimum bakteri sekitar pH 7, sedangkan untuk bakteri asidofilik obligat (Thiobacillus, Sulfolobus) tumbuh pesat pada $\mathrm{pH}$ 2. Pada umumnya bakteri tumbuh seiring dengan turunnya $\mathrm{pH}$ atau suasana medium menjadi asam yang disebabkan terbentuknya produk (asam) dari kegiatan metabolisme. Setelah berakhirnya fase log produksi asam asetat cenderung stabil atau jikapun terjadi penambahan hanya sedikit. Pada limbah cair tahu dengan penggumpal asam asetat $\left(\mathrm{CH}_{3} \mathrm{COOH}\right)$ mempunyai $\mathrm{pH}$ yang rendah yaitu dengan $\mathrm{pH}$ awal pengamatan sebesar 4,91 lebih rendah dibandingkan $\mathrm{pH}$ awal pengamatan limbah cair tahu yang digumpalkan dengan kalsium sulfat $\left(\mathrm{CaSO}_{4}\right)$ yaitu sebesar 8,97. Faktor yang ketiga yaitu substrat, untuk substrat pada limbah cair tahu yang digumpalkan dengan kalsium sulfat $\left(\mathrm{CaSO}_{4}\right)$ mempunyai kandungan glukosa (gula reduksi) awal lebih tinggi $(5,3038 \mathrm{mg} / \mathrm{ml})$ daripada limbah cair tahu dengan penggumpal asam asetat $\left(\mathrm{CH}_{3} \mathrm{COOH}\right)(1,3263 \mathrm{mg} / \mathrm{ml})$. Meskipun limbah cair tahu yang digumpalkan dengan kalsium sulfat $\left(\mathrm{CaSO}_{4}\right)$ mempunyai kandungan substrat awal lebih tinggi daripada limbah cair tahu dengan penggumpal asam asetat $\left(\mathrm{CH}_{3} \mathrm{COOH}\right)$, akan tetapi produk yang dihasilkan ternyata lebih besar pada limbah cair tahu dengan penggumpal asam asetat $\left(\mathrm{CH}_{3} \mathrm{COOH}\right)$ daripada limbah cair tahu yang digumpalkan dengan kalsium sulfat $\left(\mathrm{CaSO}_{4}\right)$. Hal ini disebabkan karena faktor $\mathrm{pH}$ awal pada limbah cair tahu dengan penggumpal asam asetat $\left(\mathrm{CH}_{3} \mathrm{COOH}\right)$ yaitu sebesar 4,91 mendekati $\mathrm{pH}$ optimum bakteri asetogenik yaitu $\mathrm{pH}$ 2. Sedangkan untuk limbah cair tahu yang digumpalkan dengan kalsium sulfat $\left(\mathrm{CaSO}_{4}\right)$ mempunyai $\mathrm{pH}$ awal 8,97 yang cenderung basa serta jauh dari $\mathrm{pH}$ 2. Dengan demikian aktivitas bakteri untuk menghasilkan produk (asam asetat) pada limbah cair tahu dengan penggumpal asam asetat $\left(\mathrm{CH}_{3} \mathrm{COOH}\right)$ lebih tinggi dibandingkan pada limbah cair tahu yang digumpalkan dengan kalsium sulfat $\left(\mathrm{CaSO}_{4}\right)$. Jadi aktivitas pembentukan produk oleh baketri asetogenik dipengaruhi oleh tiga faktor yaitu suhu, $\mathrm{pH}$ dan substrat saling berhubungan dan saling mempengaruhi dalam aktivitas bakteri tersebut.

\section{KESIMPULAN}

Kesimpulan dari penelitian besarnya nilai kecepatan pertumbuhan spesifik ( ${ }^{\mu}$ ) pada limbah cair tahu dengan penggumpal asam asetat $\left(\mathrm{CH}_{3} \mathrm{COOH}\right)$ adalah $0,3015 / \mathrm{jam}$ dan pada limbah cair tahu dengan penggumpal kalsium sulfat $\left(\mathrm{CaSO}_{4}\right)$ adalah 0,2174/jam.

Besarnya waktu penggandaan sel ( td ) pada limbah cair tahu dengan penggumpal asam asetat $\left(\mathrm{CH}_{3} \mathrm{COOH}\right)$ adalah 2,2991 jam dan pada limbah cair tahu dengan penggumpal kalsium sulfat adalah $\left(\mathrm{CaSO}_{4}\right)$ 3,1877 jam.

Besarnya derajat multiplikasi (n) pada limbah cair tahu dengan penggumpal asam asetat $\left(\mathrm{CH}_{3} \mathrm{COOH}\right)$ adalah 2,605 kali dan pada limbah cair tahu dengan penggumpal kalsium sulfat adalah $\left(\mathrm{CaSO}_{4}\right)$ 1,880 kali.

Besarnya Hasil Pertumbuhan ( $\mathrm{Yx} / \mathrm{s})$ dan Pembentukan Produk (Yp/s) berurutan pada limbah cair tahu dengan penggumpal asam asetat $\left(\mathrm{CH}_{3} \mathrm{COOH}\right)$ adalah $8,1 \times 10^{9} \mathrm{cfu} / \mathrm{mg}$ dan 1,7237 serta pada limbah cair tahu dengan penggumpal kalsium sulfat $\left(\mathrm{CaSO}_{4}\right)$ adalah $8,1 \times 10^{7} \mathrm{cfu} / \mathrm{mg}$ dan 0,0306 .

Besarnya efisiensi pembentukan asam asetat selama fermentasi pada limbah cair tahu dengan penggumpal asam asetat $\left(\mathrm{CH}_{3} \mathrm{COOH}\right)$ adalah 15,1376 dan pada limbah cair tahu dengan penggumpal kalsium sulfat $\left(\mathrm{CaSO}_{4}\right)$ adalah 2,5699.

Jenis asam yang terdeteksi adalah asam asetat, baik pada limbah cair tahu dengan penggumpal asam asetat $\left(\mathrm{CH}_{3} \mathrm{COOH}\right)$ maupun pada limbah cair tahu dengan penggumpal kalsium sulfat $\left(\mathrm{CaSO}_{4}\right)$.

Jumlah asam asetat sampel limbah cair tahu dengan penggumpal asam asetat $\left(\mathrm{CH}_{3} \mathrm{COOH}\right)$ pada jam ke-0, jam ke-2, jam ke8 dan jam ke-24 adalah berturut-turut yaitu, $0,93522 \mathrm{mg} / \mathrm{ml} ; 1,13736 \mathrm{mg} / \mathrm{ml} ; 1,89066$ $\mathrm{mg} / \mathrm{ml}$ dan $1,90482 \mathrm{mg} / \mathrm{ml}$. Sedangkan pada sampel limbah cair tahu yang digumpalkan dengan kalsium sulfat $\left(\mathrm{CaSO}_{4}\right)$ jumlah asam asetat pada jam ke-0, jam ke-4, jam ke-10 dan jam ke-24 yaitu masing-masing 0,33642 $\mathrm{mg} / \mathrm{ml} ; 0,63942 \mathrm{mg} / \mathrm{ml} ; 0,87324 \mathrm{mg} / \mathrm{ml}$ dan $0,99552 \mathrm{mg} / \mathrm{ml}$. 


\section{DAFTAR PUSTAKA}

Amaru, Kharistya. 2004. metana sebagai hasil dari dekomposisi bahan organik di TPA dan lindi sebagai sumber pencemar air tanah.

http://kharistya.wordpress.com/2005/12/

(diakses pada 1 Januari 2010).

Anonima . 2010. Penerapan prinsip waste to product dalam pengolahan limbah pabrik tahu.

http://onlinebuku.com/2009/01/03/wasteto-product-dalam-pengelolaan-limbahpabrik-tahu/comment-page-1/. (diakses pada 1 Januari 2010).

Bitton, Gabriel. 2005. Waste water microbiology. A. Jhon Wiley \& Sons. Florida.

Damanhuri, et.al. 1997. The role of recirculation in increasing efficiency of anaerobic and aerobic wastewater treatment of tofu industry. Proceeding of The Indonesian Biotechnology Conference, Jakarta.

Kuswardhani, I. 1985. Mempelajari kemungkinan pemanfaatan limah cair tahu sebagai media untuk memproduksi enzim amiloglukosidase dari kapang yang diisolasi dari singkong (Manohot sp.). Skripsi-S1. TPG-Fateta.IP. Bogor

Macklin, Boy. 2009. Limbah tahu cair menjadi biogas. www.onlinebuku.com. (diakses pada 29 Januari 2010).

Nurhasan dan Pramudyanto. 1991. Penanganan air limbah pabrik tahu. Yayasan Bina Karya Lestari
(Bintari).http://www.menlh.go.id/usahake cil/index-view.php?sub=7 (diakses pada 2 Januari 2010).

Nurhasan, Pramudyanto. 1991. Penanganan air limbah tahu dalam uniek M.C.,Clara, 1999. Pemanfaatan limbah cair tahu untuk produksi enzima-amilase dari Bacillus amyloliquefaciens. Skripsi jurusan TPHP, Fakultas Teknologi Pertaian, UGM, Yogyakarta.

Polprasert, C. 1989. Organic wastes recycling. John Wiley \& Sons. Chichester, UK.

Santoso, H. B. 1993. Pembuatan tempe dan tahu kedelai bahan makanan bergizi. Penerbit Kanisius, Yogyakarta.

Sardjono, Bambang Haryono dan Djoko Wibowo. 1999. Teknologi Fermentasi. Jurusan Teknologi Pengolahan Hasil Pertanian Fakultas Teknologi Hasil Pertanian UGM. Yogyakarta.

Sugiarto. 1987. Dasar-dasar Pengelolaan Air Limbah. Universitas Indonesia, Jakarta.

Uniek M.C.,Clara. 1999. Pemanfaatan limbah cair tahu untuk produksi Enzima-amilase dari Bacillus amyloliquefaciens. Skripsi jurusan TPHP,Fakultas Teknologi Pertaian, UGM, Yogyakarta.

Wibowo, Djoko, dkk. 1990. Teknologi Fermentasi. PAU Pangan dan Gizi UGM. Yogyakarta.

Wijaya, Bayu. 2008. Potensi Limah Cair Thau untuk Produksi Biogas sebagai energi alternative. UGM. Yogyakarta. 